cabeça e ela corria, o xale balançando ao vento, os ramos de café queimados pelo frio lanhando-lhe o rosto, o franzino corpo. Para onde prosseguir? A voz do crioulo gritando seu nome entre porcarias estava em seus calcanhares, mas ela corria e disparava e... caiu. Levantou-se e impulsionou o corpo sempre em frente, mas algo como uma parede derrubou-a de volta à terra fria, estéril. Ainda tonta viu-se levantar pelo braço e com a outra mão recolheu o xale. - Ela está aqui, companheiro! Gritava o ruivo, mordendo os dentes. Perturbada, ela ia do rosto do marido ao do pérfido Tiago. Agora começava a compreender. - Hein, sabe por quê? Por que uma mulher perde a vergonha?! Urrou o marido passando as mảos pelo fino pescoço. Como cordeiro, indefesa, Agnes entregou-se. O ar gélido começou a faltar. Sentiu o chão sumir aos pés quando o moreno levantou-a frente ao êxtase do outro, o ruivo. - Aperta, aperta! Grunhia ele. - Quero ver se essa vagabunda enjeita outro... e, de súbito, Agnes sentiu o corpo batendo pesadamente no chäo úmido, quase tão gelado quanto ela. Era difícil respirar. Puxava o ar desesperadamente e ouvia murmúrios, mas não enxergava nada. Demorou até que o sangue corresse normalmente por suas veias. Queria abrir os olhos, mas tinha medo de enxergar o que se passava. Uma mão pequena, tão calosa quanto a sua, e mais enrugada, começou a aquecer as dela. Abriu os olhos, viu a mulher da talha d'água, sua companheira. Reconheceu o quarto, a cama limpa, como ela gostava. Quis saber do acontecido. O ruivo estava morto, varado pelo facão do marido. Mas ele também se acabara na faca do outro. Agnes virou o rosto fixando um ponto na parede. Năo iria chorar. Ele não a queria seca? Até ali ela fora e agora seria. - Ele pediu perdão antes de se ir... lamuriou-se a mulher. Agnes fechou os olhos. $\mathrm{E}$ uma repentina compaixão foi se instalando nela. Levantou-se, abriu as caixas onde guardava suas coisas, poucas. Escolheu alguns pertences, amarrou tudo numa trouxa. O povo, do lado de fora, contrito. Olhou para todos sem ver nenhum e, passando por eles, ainda disse: - Depois vou cuidar de mim... e caminhou para o cafezal; recolheu caroços do fruto que não tinham maturado e guardou-os entre os seios. Alguns passos a frente o tinto vermelho coloria os restos de neve e folhas junto ao pé de café. Agnes puxou o xale cobrindo-se. Levantou o rosto para receber um pouco de sol e viu, num ramo, uma flor branca que persistia. Sorriu. Algo sobrevivera.

\section{POEMAS INÉDITOS}

Sebastiäo Milani

\section{TEORIA DA CARNE E DA REENCARNAÇÃO}

Pensava ter encontrado a solução.

Antes era duro suportar a ausência.

Durante, o desespero das taras e da fome.

Então come homem, come que teu mal é fome.

Passa o tempo. Passou a luz, vieram as horas, veio a escuridão E a fome voltou.

O homem pensou que não há solução.

O homem está só na cama que começa, enquanto o sono não vem.

Ele sabe que um dia acaba em uma noite muito longa.

Ele pensa em encurtar o dia. Pode, mas não deve.

O sono solitário da noite que não acaba,

É a solução para a solidão do dia?

- Doutorando em Semiótica c Lingüística Geral - FFLCH/USP. 


\section{NADA COMO UMA NOITE ENTRE DOIS DIAS, SERÁ?}

\section{APENAS UMA PALAVRA}

Procurei durante horas as palavras.

Encontrei na boca da criança faminta.

Encontrei nos olhos de uma prostituta.

Na fila dos homens sem lar e com fome.

Procurei durante horas as palavras.

Procurei-as, por fim, no meu coração.

Ontem, depois de uma pinga, eu sorri.

Só um bêbado saberá porquê.

Bebi porque estava só.

Bebi, porque só estou.

Bebi porque estarei so.

Maria diz que me ama, mas só me quer.

José, meu amigo, nunca me visitou.

Eu, procuro a palavra.

Desesperadamente...

\section{CLARA LINGÜÍSTICA DOS PRAZERES}

Eu a conheci nas letras.

Em português primeiro,

Italiano, espanhol e francês.

Depois, clara estava em mim.

Tăo pura, tão clara que eu me apaixonei.

Paixão semiótica essa: simples e complexa.

Tão viva quanto clara, gema e casca.

Falar dela e por ela é fazer amor,

Fazer amor com a língua,

Amor de amigo, nāo de amantes.

Sou seu filho, sou seu pai.

Criado e criador.

Amado e amador.

Clara lingüística dos prazeres.

Clara é seu nome e sua cor.

Lingüística é o transporte no caso.

Dos prazeres que só quem ama por amor de amizade é capaz de sentir.

Clara lingüística dos prazeres,

Lingüistica clara dos prazeres,

Qual seja a forma,

Qual seja o significado,

Qual seja o seu nome.

Será sempre minha Clara,

Será sempre minha lingüística,

Será sempre um prazer estar com elas. 


\section{LIBERDADE DOS LOUCOS}

Disperta em mim uma dor:

- Faço o que nunca fiz.

- Quero o que nunca quis.

Livre nāo sou mais,

Liberto como jamais,

Liberdade que escolhi.

Não sei o que penso,

Não quero pensar.

Digo sim e me ajoelho!

Chuta-me e eu me entrego!

Diz não e eu morro!

Sou mais livre agora que não sou livre.

Mando rosas e faço versos.

Só se está vivo quando se morre por amor.

Estou morto; viverei para sempre.

\section{SOMENTE EU!}

Era feliz e não sabia!

Agora escrevo poesia!

Eu, era feliz e sabia,

Mas não escrevia poesia!

Sou infeliz,

Mas escrevo poesia.

\section{ROLANDO A BOLA}

Rolou a bola! Rolou a bola!

Mas o craque está apático.

\section{Role bola!}

Enrole-se em ritmos descompassados.

Role bola, de-pé-em-pé, em pé de craque.

De-pé-em-pé; em pé, a torcida.

Que torcida? E o craque? Este não sabe ainda como vai terminar este jogo!

Jogo de bola. De bola que corre entre linhas.

Rola a bola, leve, até o fim. Mas, qual é o fim?

Falta! Falta, sim, falta a luz dos Bandeiras.

Falta o brilho do craque.

Olha ela com ele, ele voltou.

A torcida em pé se enflama, em flâmulas.

Olha o craque com a bola nos pés.

E a torcida grita, vibra! Gol...!

E a bola rola!

Rola, de novo, de-pé-em-pé.

Não é o fim, não acabou.

Para o craque o jogo não acaba, quem acaba é o tempo. 


\section{ESCOLA}

Eu, ex-colo.

Você: ex-cola.

Nós estudantes, ex-colantes, estabilizados.

Pública;

Particular;

Clandestina;

Em greve.

Ex-criadora de cidadãos;

Ex-padronizadora;

Niveladora dos aflitos.

Social;

Democrática;

Igual;

Temporal;

Atualizada com a verdade ético-moral.

\section{Chateante,}

Namorada,

Escrita,

Independência,

Obrigação,

Muitos amigos para a vida inteira.

Autoridade,

Autorizada,
Poder.

Felicidade,

Sobrevivência,

Dedicação,

Amor ao proximo.

Um poço de virtude, de sabedoria e de hipocrisia.

Equalização social e moral.

Uniformização dos aflitos.

Necessária,

Autoritária,

Solução.

Possibilitante, criadora, unificadora, registrante, Amada, odiada, solitária, solidária, para sempre. Amém!

\section{SINCERIDADE}

Pedi socorro e ninguém ouviu.

Pedi ajuda e ninguém ouviu.

Pedi misericordia e Deus me ouviu!

Ouvi um grito e socorri.

Ouvi um lamento e ajudei.

O meu lamento comigo vai! 
Pedi socorro e um me ouviu!

Pedi ajuda e dois me ouviram!

Quando nāo cria mais,

Olha quantos me ouviram!

Nāo era quem pensava e queria.

Mas é tão bom!

Nāo importa de onde venha,

Melhor que venha de um coração puro.

Estou sendo amado por tantos,

Que Deus me faço grato!

\section{HOMEM: APENAS, HOMEM!}

Um homem desejou ser Deus!

O homem achou que era maior que os outros!

Homem é apenas homem! Quando muito, pode ser, instrumento de Deus!

- Ele achou que devia defender outros homens!

- Ele achou que podia defendê-los?

- Ele achou que era instrumento de Deus!

Provou, tão somente, que era homem!

\section{BIBLIOTECA}

Silêncio!

Silêncio!

- Tosse! Tosse!

Quantas mesas:

Vários moços,

Muitas moças.

Nāo têm nome,

Não têm som.

Não têm para mim!

No canto um que é moreno, agita-se entre folhas.

Algém que fala atrás de mim,

- Silêncio!

Fez-me interromper.

O tossir masculino se confundiu com as paredes.

Esse é um lugar para muitas pessoas.

Lá, no fundo, do outro lado, alguém me olha escrever.

O que será que ele pensa que faço?

Que silêncio...! 


\section{BELA ILUSÃO}

\section{Bela ilusão essa,}

Essa que nos faz gemer.

Bela ilusão que nos faz escravos.

Nunca um homem só, está seguro.

Nunca um homem deve ser deixado só.

Nunca um homem foi tão solitário,

quanto solitário é o homem que foi abandonado.

Eu nem sei o seu nome.

Eu por medo e inexperiência me deixei iludir também.

Eu não poderia amá-lo.

Sinto uma dor imensa, porque não soube amá-lo.

Pobre homem só, que se entrega para outros homens, também solitários, que compram e não sabem da dor.

Pobre homem só. Pobre de mim que estou pagando.

Eu também já fui muito solitário. Não há cura, que não seja o Amor.

Pobre homem solitário que estiver sem fé.

\section{MINHA POESIA}

Ela está dentro de mim, lá dentro de mim. Não se manifesta se não for assim.

Só se manifesta através de mim.

Às vezes, ela e eu somos iguais.

Agora somos iguais.

Mas depois, ela é livre, independente, Eu não sou mais ela, sou o dono dela.

Bem lá dentro de mim, ela fica;

Eu me entendo com ela e ela comigo;

Ela sabe que depende de mim;

Eu sei que não posso viver sem ela.

Ela é a minha saivação,

A minha força libertadora.

Nela, eu sou livre, totalmente.

Você só vai me ver

Se me olhar através dela.

Ela sabe quem sou,

Ela, s6, é que pode lhes contar quem sou.

Ela sou eu.

Eu não entendo porque me tornei ela,

Mas sei que não há sensibilidade sem dor,

$\mathrm{E}$, sei que não há poesia sem sensibilidade.

Sei que não existo sem a poesia.

Sou completamente insignificante.

Mas quando estou com ela sou invencível. 


\section{AMOR: VOCÊ ENTENDE?}

Queria saber falar do meu amor!

Queria saber mostrar o meu amor!

Não sei mais o que fazer!

Será que eu não soube ser explícito!

Será que ainda não fiz e não falei certo!

Queria saber falar do meu amor!

Queria que vocês entendessem esse meu amor!

Eu juro! Foi tudo por amor! Por amor!

Queria muito mesmo que você me entendesse!

Queria saber falar do meu amor!

Queria saber dizer do meu amor!

Queria que você me entendesse!

Queria saber se você entende o meu amor!

\section{CADERNO DE POESIA}

Tem tudo desde o começo até o fim Meias palavras, pedaços de mim.

Formas forjadas de claros desejos, Despetaladas em raros lampejos.

Caderno de mim-poesia:

Noites sem nenhum por vir;

Covas românticas vadias.

Nada são seus desdolorir.

\section{MÚSICA BRASILEIRA}

Bate os bumbuns no batiçundum. Bate o baco do balaco-baco.

- Chora viola!!!

Nestes versos tão singelos

Uma viola de alma dilacerada

Canta para sua bela, seu amor.

O chamego nas cadeiras da donzela, O chinelo e o poeirão,

A sanfona lá na roça

é noite de Săo Joảo. 
A água nos caracóis dos seus cabelos

Em ver noites de luar

Faz-me pensar em sertanias,

Em ser adolescente e te pegar na escola.

Toda menina que enjoa da boneca,

Põe uma saia bem curtinha

E sai para namorar!!!

\section{AMOR}

Tantos já disseram do amor o seu valor.

Clássicas oposiçōes do que é sem ser, sendo.

Românticas razões ideais: amor-perfeito.

Modernas razões, sem-razōes de amor sem fim.

De onde vem que se explica e não se entende?

Quem é que sabe, mas nāo sabe, e sabe?

\section{Eu te amo. Não basta!}

Amo-te como amo a mim mesmo;

Amo-te, de dentro de mim saíste;

Deus é amor. Nāo basta!

Não basta nada para saber do amor!

Não basta nem mesmo explicar:
Amor é amor e pronto!

Sabe, e só sabe, quem experimentou.

Por isso, não perguntem,

Mesmo sabendo, quem poderia explicar!?

Amar sem conta

\section{PARA AMAR BASTA AMAR}

Não há amor sem limites,

Porque se é sem limites,

Limitado está pelo infinito.

Amor é o inverso do substantivo.

Dizer que o amor é,

É dizer que há adjetivo.

Amor é sem conta;

$\mathrm{O}$ amor não é aquilo que sinto,

Amor não pode ser sentido.

O amor não é nada, mas é tudo.

Amor é um estado, mas não é.

Amor não é, não está, não mede.

O amor simplesmente não pode ser,

Porque se for, não é amor.

O amor nāo é, e não pode ser,

Porque ele não existe para aqueles que, como eu, ainda são matéria. 